OPEN ACCESS

Edited by:

Cornelia E. Nauen,

Mundus maris, Belgium

Reviewed by:

Ricardo Calado,

University of Aveiro, Portugal

Li Li,

Ocean University of China, China

*Correspondence:

Lillian Hansen

lillian.hansen@ruralis.no

Specialty section:

This article was submitted to Marine Fisheries, Aquaculture

and Living Resources,

a section of the journal

Frontiers in Marine Science

Received: 14 September 2019 Accepted: 25 November 2019

Published: 17 December 2019

Citation:

Hansen L (2019) The Weak Sustainability of the Salmon Feed Transition in Norway - A Bioeconomic Case Study. Front. Mar. Sci. 6:764 doi: 10.3389/fmars.2019.00764

\section{The Weak Sustainability of the Salmon Feed Transition in Norway - A Bioeconomic Case Study}

\author{
Lillian Hansen ${ }^{1,2 *}$
}

${ }^{1}$ Institute for Rural and Regional Research (RURALIS), Trondheim, Norway, ${ }^{2}$ Department of Sociology and Political Science, Norwegian University of Science and Technology, Trondheim, Norway

This paper investigates transition pathways using an example from the bioeconomy: salmon farming and feed development in Norway. With a Multi-Level Perspective (MLP), the analysis shows how a crucial biological input factor, feed, was gradually developed and innovated through interactions among technologies, institutions, and landscape (external) pressures, with the industry's ambitions of becoming more sustainable. The case story presents the start of salmon farming as an example of an incremental transformation pathway with gradual reorientations in the 1960s', where the shift from wet feed to dry, extruded feed was a crucial technological enabler. At the start of the 1990s, strong exogenous changes, including an economic crisis of overproduction and declines in salmon prices, led to extensive institutional changes. Shifts in ownership and the introduction of feed quotas brought a substitution pathway, whereby salmon farming became a national economic project. As production recovered, however, overfishing for feed became a concern. From the late 1990s on, the sociotechnical regime followed a reconfiguration pathway with the innovation of among others plant-based feed input. Over time, using vegetarian salmon feed has had unintended consequences, particularly environmental and social problems related to soy production. While neither technologies nor transitions in themselves are sustainable, this case exhibits a shift in transition pathways and how the salmon farming industry was able to respond to different sustainability concerns over time. Yet, as the transition to soy-based salmon feed demonstrates, this development entails only a weak sustainability with a main focus on economic sustainability, which also could be the case as new innovative feed substitutions continue to evolve. This finding is line with the critique of the bioeconomy agenda for paying insufficient attention to environmental sustainability and for failing to challenge predominant structures in society.

Keywords: bioeconomy, salmon feed, sustainability, sociotechnical regimes, transition pathways, Multi-Level Perspective 


\section{INTRODUCTION}

The bioeconomy has been suggested as one solution (Swinnen and Riera, 2013) to the grand societal challenges of our time (Lund Declaration, 2009). A biobased economy, or the bioeconomy, can be understood as "an economy where the basic building blocks for materials, chemicals and energy are derived from renewable biological resources, such as plant and animal sources" (McCormick and Kautto, 2013, p. 2590, based on OECD, 2009; EuropaBio, 2011; EC, 2012). With this broad definition, the bioeconomy includes primary and traditional branches such as farming, forestry, and fisheries, and newer branches such as aquaculture, biorefineries, bioenergy, and waste recycling (Scarlat et al., 2015; European Technology Platforms, 2017). How the bioeconomy works in practice has the potential to impact several of the UN sustainability goals (United Nations, 2015), including food security and nutrition (goal 2), sustainable economic growth and employment (goal 8), combatting climate changes (goal 13), and securing marine (goal 14) and terrestrial resources (goal 15). Across the world, many countries have developed their own bioeconomy strategies, and many European policy frameworks exhibit similarities in their emphasis on economic output and a broad sectoral focus (McCormick and Kautto, 2013). Other analysts find that bioeconomy policies do not pay enough attention to environmental sustainability. Staffas et al. (2013), among others, find that the main emphasis of national strategies is often to enhance the economy of the nation and provide new employment and business possibilities, whereas sustainability and resource availability are addressed only to a limited extent. Bugge et al. (2016) find that the consequences in terms of environmental protection and climate change effects are rarely assessed (Duchesne and Wetzel, 2003; Ollikainen, 2014). Therefore, the question arises: how can the bioeconomy contribute to solving these various challenges in a way that is sustainable environmentally and socially, as well as economically? The national strategy for the Norwegian bioeconomy emphasizes its role of new value creation, and points at issues such as synergies across value chains, as well as solving environmental (i.e., climate) and societal (i.e., food supply) challenges. Salmon farming and salmon feed play a prominent role in this document (Government of Norway, 2016). What can be learned from an industry that presumably has managed to make use of synergies across sectors and knowledge flow between established and new branches, in achieving greater sustainability?

The main purpose of this study is to investigate whether the transition in salmon feed can be considered sustainable. The key questions are: What are the outcomes in terms of meeting societal and environmental as well as economic sustainability challenges, and what might those consequences mean for an expanding bioeconomy? This paper contributes with a detailed description of complex dynamics in a prominent case in the bioeconomy in Norway: aquaculture, particularly fish feed, the economically most significant part of this sector. A Multi-Level Perspective (MLP) and transition pathways framework are applied in order to understand technological transformations in salmon feed as part of larger, sociotechnical systems (Geels, 2002, 2004; Geels and Schot, 2007; Geels et al., 2016). The framework focuses on actors' relation to institutions and technology. However, this study contributes with sustainability framings as an important aspect to understand transitions.

The remainder of this section explains the most relevant aspects of the concept of sustainability, the critiques often made of it, and outlines the theoretical framework used in the analysis, the MLP and its typology of transition pathways. The next section describes the case-oriented method and types of data used to establish the case story. The paper then presents the case story through an analysis of the different transition pathways, focusing on interactions among actors, technologies, institutions, and framings of sustainability. Next, it discusses these findings in light of the transition pathways and definitions of sustainability and their implications for future development.

\section{Theoretical Approach Sustainability}

Dryzek's (2013) The Politics of the Earth traces how the concept of sustainability has expanded over time, from among others an initial focus on pollution, wilderness preservation, population growth, and the depletion of natural resources to more recent concerns about energy supply, biodiversity, climate change, depletion of the ozone layer, the protection of whole ecosystems, food security, and genetically modified organisms. Environmental problems by definition are found at the intersection of ecosystems and human social systems (Dryzek, 2013). The Brundtland (1987), "sustainable development" agenda has become the dominant global discourse of ecological concern. The agenda has equity at its base, as it emphasizes not just strong economic performance but intragenerational and intergenerational equity, with a balanced consideration of economic and environmental goals and objectives. This concept brings together what is commonly called the three pillars of sustainable developmenteconomic development, social development, and ecological development-under one societal goal of sustainability. These pillars were first introduced in the famous Venn diagram by Barbier (1987, p. 104), and later referred to as the "triple bottom line" (see Elkington, 1998). Figure 1 is considered a standard approach to the concept of sustainability.

The central zone, the "equitable criterion" or "just" sustainability, incorporates the Brundtland Commission's assumption that only equitable choices can endure over the long run. However, this understanding of sustainability has gotten critique. Giddings et al. (2002) argue that the problem with the sustainable development concept is that the economy often is given priority in practice. Rather, they argue, these pillars are interconnected; the economy is dependent on society and the environment, while human existence and society are dependent on and live within the environment 


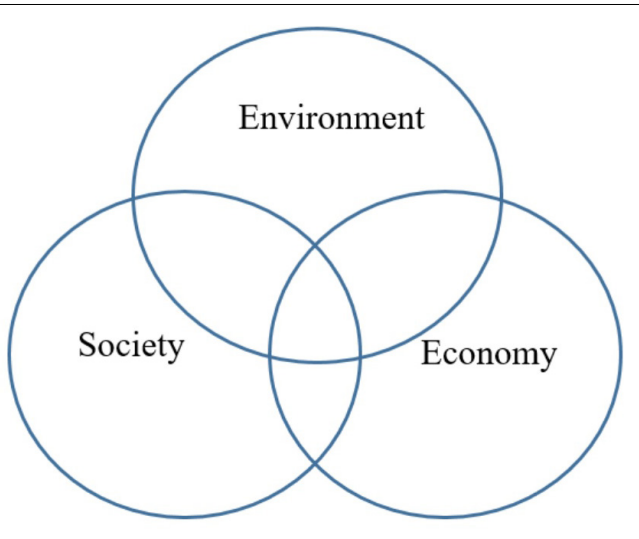

FIGURE 1 | Common diagrammatic representation of the three pillars of sustainability, adapted from Barbier (1987: 104).

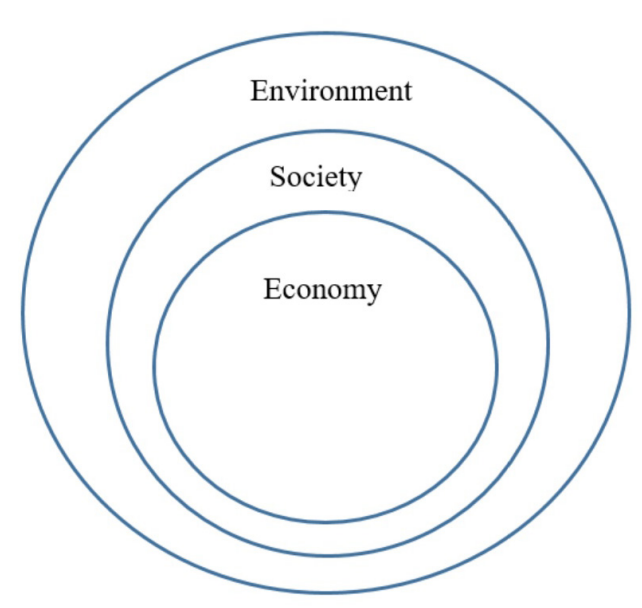

FIGURE 2 | Nested sustainable development - the economy is dependent on society and both dependent on the environment. Source: Giddings et al. (2002, p. 192).

(Figure 2). The implication is that the environment is the most important element.

\section{Weak and Strong Sustainability}

The above debate on operationalization of sustainability segues into a debate about "weak" and "strong" sustainability. Under weak sustainability, the assumption is that natural capital and manufactured capital are essentially substitutable. In addition, it is assumed that there are no differences between the kinds of well-being they produce, as long as the total capital does not decrease. The general theory behind weak sustainability is neoclassical: everything, including nature, has a market price and is for that reason tradable (Dasgupta and Heal, 1974; Solow, 1974). The underlying assumptions are thus that there is a superabundance of natural resources, and that technological progress has the ability to increase the productivity of the natural capital stock faster than it is being depleted. Critics argue that this substitutability should be limited, given the crucial elements that natural capital provides for human existence and well-being (Pelenc and Ballet, 2015) and as part of several complex systems (see, e.g., Noël and O'Connor, 1998; Ekins et al., 2003). Moreover, these critics argue natural capital is not interchangeable with human-made capital. First, the extinction of species and the combustion of fossil fuels is irreversible (Ekins et al., 2003). Second, since manufactured capital requires natural capital for its production, it can never be a complete substitute for the biophysical structures of natural capital (Ekins et al., 2003). Third, an increase in the future consumption of manufactured capital is not an appropriate substitute for losses of natural capital (see, e.g., Dedeurwaerdere, 2014; in UNDP, 2011; Pelenc and Ballet, 2015). Essentially, the advocates of strong sustainability posit that the economic pillar should not dominate the other two pillars of sustainable development (Elkington, 1998; Rideout, 2016). Conversely, when the economic pillar dominates the others, this implies "weak sustainability." Dedeurwaerdere (2014) explains how weak sustainability is based on the assumption that economic growth can be decoupled from material throughput via the decreasing use of natural resources in production systems, particularly by means of technological innovation. Evidence of such decoupling over time, however, is decidedly mixed. Relative decoupling has definitely increased with decreases in the use of natural capital per unit of economic output, in part because of more efficient resource use or a reduction in pollution intensity per unit of economic output. Dedeurwaerdere contends that, although relative decoupling is a necessary condition for ecological sustainability, it is not sufficient. Absolute decoupling is needed, and it has not happened yet. Rather, energy consumption in absolute terms has continued to grow in the 1975-2000 period ${ }^{1}$ (Jackson, 2009). Also with respect to general resource use, only a relative decoupling is witnessed (1980-2008), as in absolute terms the use of for instance land, water and fertilizer are still increasing (Dittrich et al., 2012). Is this also true for salmon farming and feed?

\section{Sustainability in Aquaculture}

Bailey (2014) has analyzed sustainability in the salmon farming industry by applying the three pillars of sustainability. Emphasizing the need for trade-offs between these different types of sustainability, she suggests that multiple decisionmaking structures are essential for handling such complex issues and nudging the industry in a more sustainable direction. For example, the democratic system, working closely with environmental groups in civil society, may lead to the adoption of high environmental standards; civil society may instigate certification systems; in the market, retailers may promote "sustainably produced" products; and international organizational networks and agreements may support sustainability. Bailey argues that these four types of structures bring together different types of actors who can negotiate about values, needs and preferences, and therefore collectively provide information about the economic, social, and

\footnotetext{
${ }^{1}$ Jackson (2009) shows that the OECD countries which increased their overall energy efficiency by up to 50 percent also increased their fossil fuel energy consumption or stayed at the same level. In some European countries, however,
} a degree of absolute decoupling can be observed. 
environmental aspects of sustainability. However, she might be too optimistic about what these important decision-making arenas are able to achieve. As will be discussed more in detail later, certification systems are limited by the type of actors they include, and their ability to influence more sustainable production is highly dependent on having strict enough indicators.

Bailey studies the entire salmon farming industry, and admits this is a complex task. This paper focuses more narrowly on one crucial part of salmon farming, the feed. LCA studies suggest that feed is responsible for over $90 \%$ of the environmental impact of aquaculture production (e.g., Newton and Little, 2018). The limited scope of this inquiry makes it possible to ascertain what the specific triggers for change were, how they were activated, and which people and groups were involved. This article takes a process-oriented approach to sustainability, which examines changes over time, and acknowledges that innovation and landscape (exogenous) changes are crucial. Going beyond socio-ecological and socio-economic system thinking and rather taking the departure from the socio-technical system, the typology of transition pathways based on the MLP helps to illuminate the directions that different triggers and interactions might produce, and thus suggests what made this shift more or less sustainable.

\section{Transition Pathways in the Multi-Level Perspective}

The MLP encompasses three levels: the sociotechnical regime $(\text { meso-level })^{2}$, niche innovations $\left(\right.$ micro-level) ${ }^{3}$, and the

\footnotetext{
${ }^{2}$ In this context, regime refers to the dominant, semi-coherent set of rules in a sociotechnical system. The regime is sociotechnical in the sense that it comprises both social and technical elements (Geels, 2004). A sociotechnical regime stabilizes a series of existing development trajectories, but can also lead to lock-in and path dependencies in sociotechnical systems (see, e.g., Unruh, 2000).

${ }^{3}$ Niche innovations are usually developed by small networks of dedicated actors at the fringe which are protected from ordinary market forces (Geels and Schot, 2007).
}

\section{Increasing structuration of activities in local practices}

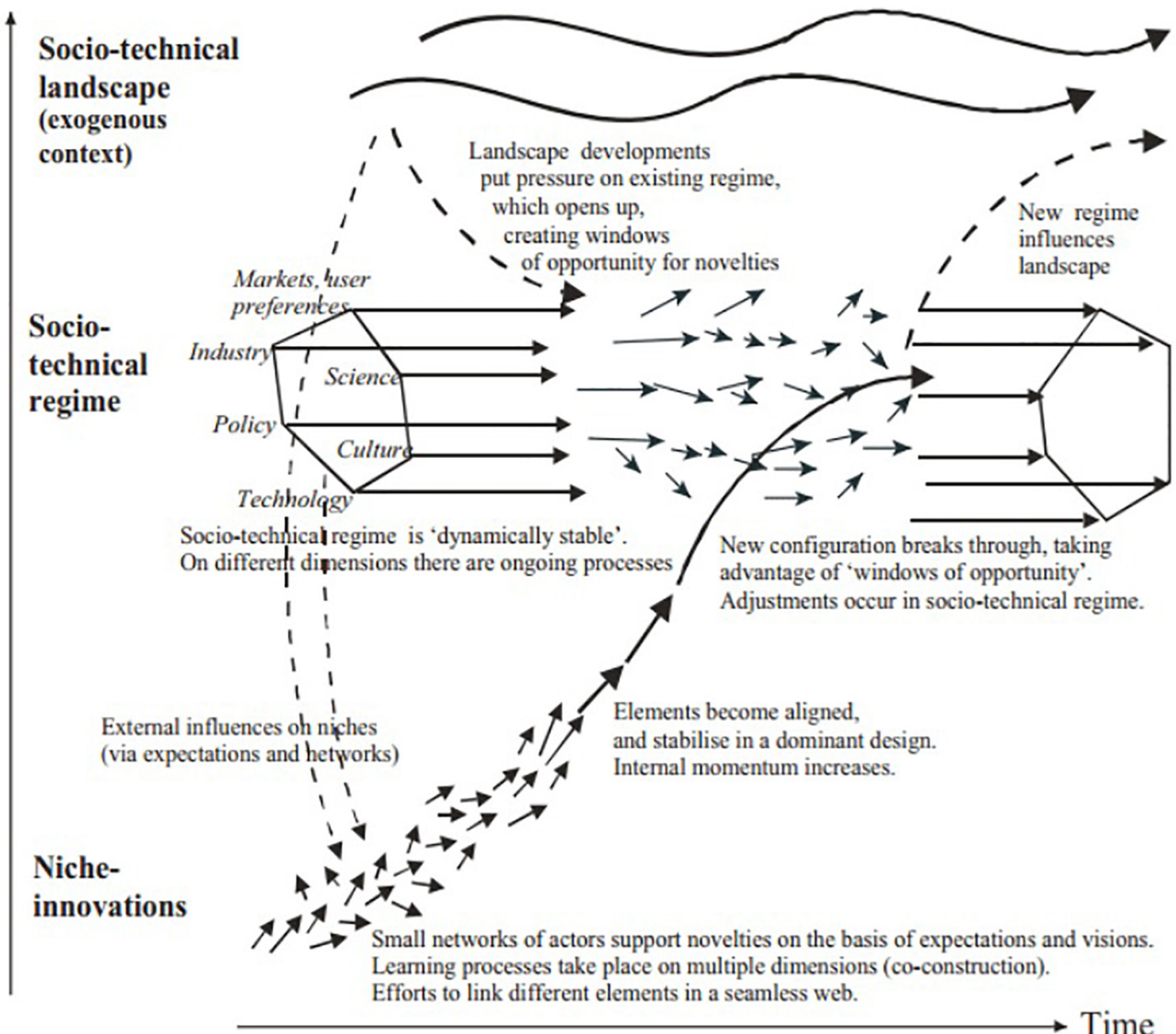

FIGURE 3 | Multi-Level Perspective on transition pathways. Source: Geels and Schot (2007, p. 401, adapted from Geels, 2002, p. 1263). 
sociotechnical landscape (macro-level, exogenous factors) ${ }^{4}$. See Figure 3.

In the MLP, transitions are defined as major transformations in the way societal functions, such as transport, housing, energy, and the food supply, are fulfilled, which take place on the regime level (Geels, 2004, 2005). As shown in Figure 3, transitions proceed in several steps and can take different directions. "It is the alignment of developments (successful processes within the niche reinforced by changes at regime level and at the level of pressure from the sociotechnical landscape) which determine if a regime shift will occur" (Kemp et al., 2001, p. 277). Geels (2010) explains that sustainability transitions differ from historical transitions by requiring multiple solutions rather than single innovations. In addition, he argues that innovation studies may need to broaden their conceptual scope to include dynamics related to civil society, social movements, and consumer behavior. In keeping with this suggestion, sustainability framings and discourses are central to the analysis presented here.

According to the MLP, regime-level changes come about through the combination of niche innovations and various forms of landscape pressure. As this process is thoroughly described in Geels $(2002$, 2004), the focus here is on transition pathways as developed by Geels and Schot (2007) and later adapted in Geels et al. (2016). The first criterion is whether niche innovations are sufficiently developed when landscape pressure occurs and whether actors see these innovations as symbiotic or disruptive in relation to existing technologies. The second criterion is whether landscape pressure is moderate or heavy. These axes generate four transition pathways, which are theorized as ideal types. In practice, transitions are neither linear nor deterministic; they may change over time, as one pathway can shift into another (Geels and Schot, 2007; Geels et al., 2016). Here are the four different pathways as described by Geels et al. (2016, adjusted from Geels and Schot, 2007).

\section{Transformation pathway}

This pathway is likely when there is moderate landscape pressure (e.g., concern regarding pollution or conservation), but niche innovations have not yet been sufficiently developed. Outsiders, such as activists, entrepreneurs, and unconventional scientists, draw attention to landscape factors. This concern may change perceptions among actors in the sociotechnical regime, leading to reorientation of innovation activities. Over time, niche innovations are added on to existing technology and knowledge. The new regime grows out of the old without disrupting its basic architecture, although there may be changes in actors and social networks.

\section{Reconfiguration pathway}

This type of transition takes place under moderate landscape pressure (e.g., concern for depleting marine resources or negative externalities) over time when symbiotic niche innovations have been sufficiently developed. Regime actors initially adopt niche

\footnotetext{
${ }^{4}$ The sociotechnical landscape forms the exogenous context outside the direct control of actors; it usually refers to macro variables, such as demography, economic crises, commodity prices, and climate changes affecting the system as a whole.
}

innovations to solve local problems and enhance performance. Their adoption triggers further, cumulative learning and changes in the basic architecture of the regime, but can also lead to unintended problems. Under continued landscape pressure, this situation can eventually lead to major reconfigurations and regime changes.

\section{Substitution pathway}

Such a transition can be expected when there is heavy pressure from the landscape (e.g., the sudden inaccessibility of a resource, or the onset of an economic crisis) and niche innovations have been sufficiently developed. Major tensions among actors in the regime and competition between old and new firms emerge. Activists and social movements may also engage. This fluid situation generates possibilities for novel solutions that have gained momentum in niches. Institutional changes will be limited when innovations are adopted just to improve the price/performance ratio of existing technologies. More sweeping institutional changes will occur if these have to be adjusted in order to adopt the niche innovation. A new technological architecture gradually pushes out the old, and new actors replace established actors. Thus, a new sociotechnical regime replaces the old one.

\section{De-alignment and re-alignment pathway}

This type of transition occurs when there are major and comprehensive landscape changes (e.g., extensive social movements, war, or major climate catastrophes) at a time when niche innovations have not yet developed. The regime rapidly comes under heavy pressure, leading to prolonged uncertainty and destabilization. Over time multiple, embryonic innovations develop and compete, leading eventually to the formation of a new regime around one of the innovations, e.g., a technology.

The sociotechnical enactment of these pathways can be analyzed in terms of actors' interactions with technology and institutions, as done by Geels et al. (2016). By including the sustainability issues that were prevalent through the transition, it creates a clearer picture of the principal possible directions that the different combinations might take and illuminate in what ways and to what extent the outcomes are sustainable. Thus, in addition to the actors, technologies, and institutions, framings of sustainability must be included to understand these changes. Indeed, the integration of sustainability considerations into the MLP is one of the major theoretical contributions made by this study.

\section{MATERIALS AND METHODS}

Complex sociotechnical transitions can fruitfully be examined through case studies (Yin, 2003). A case history constitutes a narrative (Czarniawska, 2004; Moses and Knutsen, 2012), that is, a detailed description of a case over a relevant time span. The quality of this description depends on its coherence and trustworthiness, qualities that can be achieved through the triangulation of different kinds of data. The process of constructing and analyzing the case story thus proceeded through 
the following steps. First, pinpointing value chain developments, its main constituents, and relevant contexts by analyzing media coverage. Using the online news archive Retriever Norway, searching for the words "fish feed" (fiskefôr) and "salmon farming" (lakseoppdrett) together yielded 700 pages of news articles from 1984 through 2016, which was the end date chosen for this part of the study. A total of 177 news articles contained information regarding salmon feed. Second, crucial events and meaningful periods in the cases based on the media articles were identified. Published reports, white papers, biographies, and web pages were gathered through strategic Google searches to supplement and fill in the gaps and document the viewpoints of salient actors and institutions covered in the media articles. To better understand concurrent technological developments and their potential, academic and scientific reports were collected on the topics that were prevalent from the media article search. Google Scholar was used as this search engine covers both academic journal articles and reports. Third, to confirm the relevance and accuracy of these materials and the time line they yielded, five key informants were interviewed in the autumn of 2017 and the spring of 2018. This included a company CEO, officials in two environmental NGOs, a representative of the relevant authority, and a researcher specializing in salmon feed nutrition. Interviewees represented different levels and types of actors from different sub-regimes: the private sector, the state, and non-profit organizations. Together, they comprised what Evers and Laville call the "welfare mix model" (Evers and Laville, 2004; see also Pestoff, 1992). The final case story was sent to both informants and relevant actors of the different periods, for verification and suggestions, to strengthen the quality. Transition pathways that were prevalent were outlined by applying MLP theory to each of the periods in the case history, analyzing how actors, technologies, and institutions shaped different pathways, and what roles the maturity of niche innovations and the pressures from landscape developments affected this process. Most importantly, the underlying sustainability issues that surfaced during each period were identified. The following analysis focused on how these transition pathways in feed for salmon farming affected the industry's environmental, social, and economic sustainability. Finally, it was assessed whether salmon feed development resulted in weak or strong sustainability, given the relative importance of these core strands in the most recent transition pathway.

\section{THE DEVELOPMENT OF A SOCIOTECHNICAL REGIME FOR FARMED SALMON FEED IN NORWAY, 1950-2018}

Aquaculture is the world's fastest growing food production sector, and in 2013, salmon was reported to be the largest single commodity by value (FAO, 2016). Over the past halfcentury, salmon farming has become a major part of the Norwegian bioeconomy (Falk-Andersson et al., 2016; Forbord et al., 2017). Thus, the question is what has contributed to this development, and whether it has led to an economically, socially, and environmentally sustainable food production system. Some advocates claim that increased food production in the sea can reduce pressure on marginal terrestrial land and limit deforestation (Asche, 2008; Hilborn, 2013; Asche et al., 2016, p. 200). Those claims deserve careful scrutiny, for fish farming entails its own economic, social, and environmental costs, not all of which are apparent at first glance. Even though aquaculture converts feed more efficiently than terrestrial animals/livestock, fish and seafood are not replacing meat as the meals of the growing population at a global level (Sans and Combris, 2015). Thus, despite the relative gain in sustainability, the total effect is one of higher overall protein consumption, both per capita and in absolute terms.

Fish feed is a crucial input factor in aquaculture, with potential consequences for economic, social, and environmental sustainability. In salmon farming, feed represents around half of total costs (Jakobsen et al., 2003), while the majority of the environmental impacts are related to feed use (Little et al., 2018). Therefore, understanding the development of fish feed can provide important insights about economic, environmental and social sustainability in one sector of the bioeconomy and the sociotechnical transitions that have affected it. Fish feed involves many components, including the sourcing of raw material, its nutritional values, the health and growth of the fish, technology for producing and handling feed, and the volume of demand, as well as the sustainability of its sourcing and supply. Since the beginning of modern aquaculture in the 1950s, there have been fundamental shifts in all these elements, but also long periods of continuity.

\section{Development Periods for Salmon Feed}

Through the case story, three major development periods for salmon farming and feed development in Norway can be identified: (1) 1950-1990, the shift from wet to dry feed; (2) 19901995, economic crises and major reorganization; (3) 1995-2018, the search for alternative feed sources and the development of vegetarian salmon feed.

\section{The Shift From Wet to Dry Feed, 1950-1990 Actors and institutions}

Part of the shift from wet to dry feed in salmon farming can be traced back to the 1950s, when Sweden required all hydropower producers to put out migratory fry of salmon and trout as compensation for the damage done to fish populations by the regulated watercourses. This legislation, together with the owners' interest in both hydropower and the chemical industry (particularly the Wallenberg Group), became a driver for the market development of dry fish feed (e-mail correspondence with Per Olav Skjervold, Managing Director at Vitenparken Science Center). As salmon farming grew into an industry, the Government of Norway decided in the 1970s and 1980s that fish farming should become an important new business sector in rural areas (NOU, 1977, p. 24; White paper 71, 1980; Aarset et al., 2005). The first permanent fish farming law came in 1981 with the goal of promoting small-scale production to create additional more employment opportunities in rural districts (Berge, 2001). 
The government tried to ensure that fish farming remained a "coastal industry."

\section{Actors and technologies}

In 1958 the company EWOS, established in 1931 as a Swedish producer of feed additives for agriculture, was the first in the world to develop a dry feed for salmon species. EWOS was then a daughter company of the Astra group, a Swedish pharmaceutical company supported by, among others, the wealthy Wallenberg family. Norsk Landbrukskjemi, located in Lørenskog in Eastern Norway, was then the Norwegian subsidiary of EWOS (Skjervold, 2015). The leader of the Astra group, Arne Wegerfeldt, regarded fish farming as a "future industry" in Norway and requested that Norsk Landbrukskjemi work with EWOS on developing dry feed:

With Astra's laboratory capacity and available resources. we should be able to make a dry feed for salmon as a replacement for beef liver and fish- and shrimp trimmings, which today are highly environmentally harmful and polluting. Resources will not be a limitation if future oriented ideas are presented!

(Quoted in Brundtland, 2015, p. 6).

By 1963, the Norwegian company T. Skretting AS in Rogaland had also developed a dry feed for salmon based on their own recipe. At the end of the 1960s, these two companies were marketing pelleted dry feed to salmon farms in Norway. Fish farming had moved from freshwater to saltwater, and salmon was the preferred fish species because it could be grown most efficiently (Skjervold, 2015).

Dry feed was not available as a large-scale product before the 1970s. Wet feed was the most common, given easy access to cheap industrial fish by-products and trimmings. During the 1960s EWOS tested different feed ingredients, such as yeast protein, cod-liver oil, and dogfish. Ensilage was also tested as a base for wet feed. Wet feed had many limitations; it had poor storage stability and hygienic quality, and the feeding process was difficult. A comparison between dry feed and different types of wet feed found that dry feed gave better growth (Gjedrem and Åsgård, unpublished paper cited in Skjervold, 2015, p. 47) not least, it simplified operations at fish farms. Consequently, dry feed became more competitive. In the summer of 1965, a new floating dam with trout was established in Skogsdammen in $\AA$ s, on the premises of the Norwegian College of Agriculture (NLH, Norges landbrukshøyskole, later became NMBU, Norges miljø- og biovitenskapelige universitet). The work was led by Harald Skjervold, a professor in livestock breeding who had just been introduced to fish farming by Rømcke-Moe, the director of Norsk Landbrukskjemi. Skjervold realized he could test the use of dry feed for livestock breeding by using salmon as experimental animals. Rømcke-Moe contributed living fish, feed, and feeding stations to the experiment in Skogsdammen.

Knowledge about the effective composition of feed was still sparse. The participants felt a strong need for systematic research. Achieving that was difficult, however, as the agricultural and fisheries authorities disagreed about which sector should be responsible and exercise oversight. Eventually funding from the Ministry of Agriculture allowed for nutritional research at the
Department for Poultry and Fur at NLH in close cooperation with the company Skretting and EWOS. The research was carried out at a new, specialized research station for aquaculture established in Sunndalsøra in 1971 (Nofima, 2014). Here experiments with various compositions of dry feed for various age classes of fish were carried out during the 1970s. One of the main findings was that the content of fat was very important for the growth and mortality of the salmon (Skrede, 2015). In this connection, the adoption of extruder technology and vacuum coating in the late 1970s and early 1980s was an important improvement. ${ }^{5}$ In 1983 , Skretting was able to increase the fat content from $13 \%$ to $30 \%$ in its first commercial extruded fish feed (Kyst.no., 2017). Extrusion also increased the possibilities of differentiating the feed for various age classes and types of fish. The feed research carried out in Sunndalsøra by NLH, and from 1984 on by the independent research institute AKVAFORSK, led to better growth of the fish and more efficient utilization of feed resources, as well as improved fish health and product quality. Between 1950 and 1990, salmon became the preferred species in fish farming, and dry, extruded, pelleted, vacuum-coated feed became the dominant type of feed (Ytrestøyl et al., 2014).

\section{Actors and sustainability}

Environmental sustainability seems to have been one triggering factor behind the development of the industry and of dry feed. The use of salmon fry as a compensation for hydropower facilities was a form of environmental conservation. Social sustainability was an important argument from a systemic perspective with the effort to ensure that fish farming remained a "coastal industry." The development of dry feed was used as an argument to avoid the polluting and environmentally harmful effects of wet feed. The technological possibilities of dry feed led to a more optimal use of resources, not only losing less to spoilage, but also optimizing nutrition and yielding higher growth rates of the salmon. Thus, dry feed was a more economically sustainable feed. For this period then, environmental and social arguments were used to legitimize the development of salmon farming, while its economic sustainability kept the salmon industry growing through a continued improvement of the feed.

\section{Economic Crisis and Major Institutional Reorganization, 1990-1996}

The economic crisis that occurred around 1990 can be seen as the turning point for Norwegian fish farming.

\section{Actors and system-level institutions}

During the 1970s the aquaculture industry burgeoned. The new right-wing leadership in the Fishery Ministry in 1982 initiated a liberalization of the fish farming law, while actors affected by the law sought to defend it. Because of political changes outside the fish farming sector, a new strategy on research policy designated aquaculture (havbruk) as an area for more research and capital. This policy was used as an argument for the partial deregulation of ownership in the 1985 law on the farming of fish

\footnotetext{
${ }^{5}$ Extrusion is a process that pushes a material through a specially engineered opening to give a desired shape and texture through increases in temperature, pressure, and shear force (see Floros et al., 2010).
} 
and shellfish; instead of requiring fish farm owners to reside in the coastal locality, now they were required to have only a formal connection with the municipality (later called Akvakulturloven, 2005; see Berge, 2001). A revised version of this law did not demand concessions ${ }^{6}$ for hatcheries, but only registration. The result was overinvestment, leading to overproduction of smolt ${ }^{7}$, and eventually overproduction of saleable fish (Berge, 2001). Between 1986 and 1991, exports of farmed fish increased by 250 percent, with trout and salmon the main species. This rapid increase in production contributed to economic crisis around 1990 because of price declines in international markets (Berge, 2001; Aarset et al., 2005; in Frisvoll, 2003). One result was an extensive restructuring of the industry, from many small local firms to a few large industrial corporations. Proponents argued that this shift was necessary to save the industry and enable firms to repay substantial bank loans (see, e.g., Berge, 2001; Frisvoll, 2003). This shift was also partly made possible by a legal change that allowed one person or company to own several concessions.

\section{Actors and institutions affecting feed}

Another part of the solution to the crisis was the introduction of feed quotas per concession unit, which were set by the Government of Norway in 1996 (Jakobsen et al., 2003). This regulation has had a huge impact on salmon production, alongside regulation of the size of sea pens (merder) and the density of fish in them (Berge, 2001; in Frisvoll, 2003). Einar Wathne, a group leader at Cargill Aquaculture Nutrition, commented:

It made us, as feed suppliers, part of a political regulation game, but at the same time it did something to the product development, since it did not say anything about what those kilos of feed should be comprised of. So when you had a limited number of tons of feed, there was a big turn toward making $[\ldots]$ those tons very nutritious, which changed the product profile in the direction of a very energy-dense feed [...] so you got a lower feed factor and also less strain on the environment.

\section{Actors and sustainability}

Significantly, advocates of these regulations did not base their arguments on economic or trade-related reasons, such as adjusting supply to demand, but rather emphasized their health and environmental benefits. As one proponent stated in a hearing note, prior to the law change, feed quotas "will promote quality and improve the health conditions of the farmed salmon, and reduce the pollution and emissions from the industry." Environmental sustainability had attained a stronger foothold in the politics of salmon farming (quoted in Berge, 2001, p. 277). Berge (2001) comments that the "non-thematising" of the need to regulate the industry was remarkable, obscuring the government's real motives. Perhaps these institutional changes were intended to ensure the economic security of the industry; perhaps they were

\footnotetext{
${ }^{6} \mathrm{~A}$ permit or license related to among other locality and volume, to regulate production, regional political concerns and control with the environment.

${ }^{7}$ Juvenile, emigration ready salmon
}

a response to public perceptions of the industry as a polluter. Alternatively, he hypothesizes, it was easier to gain support for the regulation of the industry through environmental arguments than through trade arguments (Berge, 2001). Whatever the motives, the result was that environmental sustainability became a stronger focus.

\section{Searching for Alternative Feed Sources and the Development of Vegetarian Salmon Feed, 1996-2018}

Initially, fishmeal was the main provider of proteins and fish oil the main source of fat in feed for farmed salmon (Laksefakta.no, 2017a). Both these components are derived from fish or parts of fish that are safe for human consumption, but for commercial reasons are not marketed directly as food (category III by-products; see Richardsen et al., 2015). Concern about limited marine feedstock, the substantial expansion of the aquaculture industry (Naylor et al., 2000; Deutsch et al., 2007; Ytrestøyl et al., 2015) following its restructuring and regulation after the 1991 crisis, and skyrocketing prices of feed combined to pose major challenges. These difficulties led to two interconnected developments. One was technological: the search for alternative sources of feed ingredients. The other was institutional: international cooperation to develop sustainability standards and, later, a law to allow the use of insects for feed or food.

\section{Actors and technologies}

Some of the first research on the use of plant material for salmon feed, which was published in Carter and Hauler (2000), showed that soybean meal and pea protein concentrate had potential to replace at least $33 \%$ of the fishmeal protein in extruded salmon feeds. Supporting these findings, Crampton et al. (2010) demonstrated that farmed salmon can be a net producer of marine protein. In 2002, the Aquaculture Protein Centre (APC) was established in Norway (Hanssen and Lie, 2012) to generate knowledge about how to replace feed ingredients that can be used for human consumption with ingredients that cannot. In trials with rainbow trout, the APC achieved normal growth rates entirely with vegetable-based feed. Other potential feed components were identified, including algae, yeast, and bacteria grown on natural gas or wooden material. According to the center, their research findings have been rapidly implemented by the industry (Hanssen and Lie, 2012). However, salmon by nature is not adapted to a vegetarian diet, so the species could not obtain all the necessary fatty acids from vegetable ingredients. It is necessary to ensure that their minimum requirement of marine oils such as EPA and $\mathrm{DHA}^{8}$ are covered. Fish by-products/trimmings, krill and genetically modified microorganisms and plants could be part of the answer. In fact, marine microalgae and other microorganisms are primary producers of EPA and DHA and have great potential to provide the necessary nutrients in salmon feed (Kleivdal et al., 2013). Salmon need at least $10 \mathrm{~g}$ of EPA/DHA per kilo feed to maintain good growth (Bou et al., 2017a). Further research showed that

\footnotetext{
${ }^{8} \mathrm{EPA}$ is the abbreviation for eicosapentaenoic acid. DHA is the abbreviation for docosahexinenoic acid, which can be converted to EPA in the body. Both are commonly known as Omega-3 fatty acids.
} 
with levels above $13 \mathrm{~g}$ of EPA/DHA per kilo feed, salmon grown in sea pens under challenging environmental conditions had lower mortality rates and were in better health (Bou et al., 2017b). Bente Ruyter, a senior researcher at Nofima, explained:

But we still don't know exactly what the dietary requirement for EPA and DHA are, where the limit value lies in different life stages and under varying environmental stressors. Today the industry uses more than $16 \mathrm{~g}$ per $\mathrm{kg}$ feed, a level that is considered more than enough to cover the dietary requirement for these fatty acids. But at the same time, we don't know. There are still some unanswered questions, such as whether we should use extra EPA/DHA in certain life phases or sickness risk areas.

The research institution Nofima is currently working on finding new sources of DHA/EPA for salmon feed by testing genetically modified rapeseed, enhanced to produce DHA/EPA from microalgae. However, Ruyter explains that even though it is the plant that is genetically modified, not the oil they extract to put in the feed, it is still considered as a GMO product.

Figure 4 shows the development in the proportions of the different types of feed ingredients in the period 1990-2016 (Aas et al., 2018). In 1990, fish feed contained about 90\% marine ingredients and no vegetable-based raw materials. In 2000, the use of marine ingredients had been halved and replaced by plant protein. In 2016, the overall proportion of marine ingredients had been reduced to $25 \%$, while the proportion of plant-based ingredients was around $70 \%$.

This change in the composition of fish feed since 1990 was to a large extent made possible through heavy research investments by several institutions. Today, the search for even more alternative feed sources continues. Challenges involving the availability and use of plant-based raw material in fish feed have led to research on other types of protein ingredients, such as wood (see, e.g., Bankefors et al., 2011; Lennartsson et al., 2014) and insects (Sánchez-Muros et al., 2014). In Norway, the Institute of Marine Research carried out a research project on insects as a protein source in fish feed from 2015-2016 (Havforskningsinstituttet, 2015).

\section{Actors and institutions}

In 2012, after an 8-year period of work, the steering committee of the Salmon Aquaculture Dialogue (SAD), initiated by the World Wildlife Fund (WWF), released a set of farm-level standards for sustainable salmon farming (WorldWildfLife.org, 2018). SAD was composed of representatives from four NGOs and five producers, from Chile, the US, Canada, and Norway. SAD identified seven key issues, with principles, criteria, and indicators for each. Two of the principles concern feed. The principle "use resources in an environmentally efficient and responsible manner" states that: raw materials in feed shall be traceable to specific fisheries and/or regions; the inclusion ratio of wild fish applicable for human consumption in fishmeal and fish oil shall be below certain limits; wild forage fish stocks shall not be overfished; and plant raw materials (e.g., soya) shall be certified and information about the inclusion of transgenic (GMO) plant material in feed shall be provided to buyers. In addition, the handling of feed shall lead to minimum losses of nutrients into the environment, e.g., through requiring less than $1 \%$ fine particles in the feed. The SAD founded the Aquaculture Stewardship Council, which oversees the certification of salmon farms in compliance with the standards (Asc-Aqua.org, 2017). In 2013, it announced that fish meeting the ASC standard would be available in stores. In Norway, 48 companies have attained the ASC standard, comprising almost half of the 100 companies worldwide that have done so (Soltveit, 2016; data as of October 27, 2016). World Wildlife Fund Norway now encourages consumers to buy ASC-certified salmon instead of non-certified

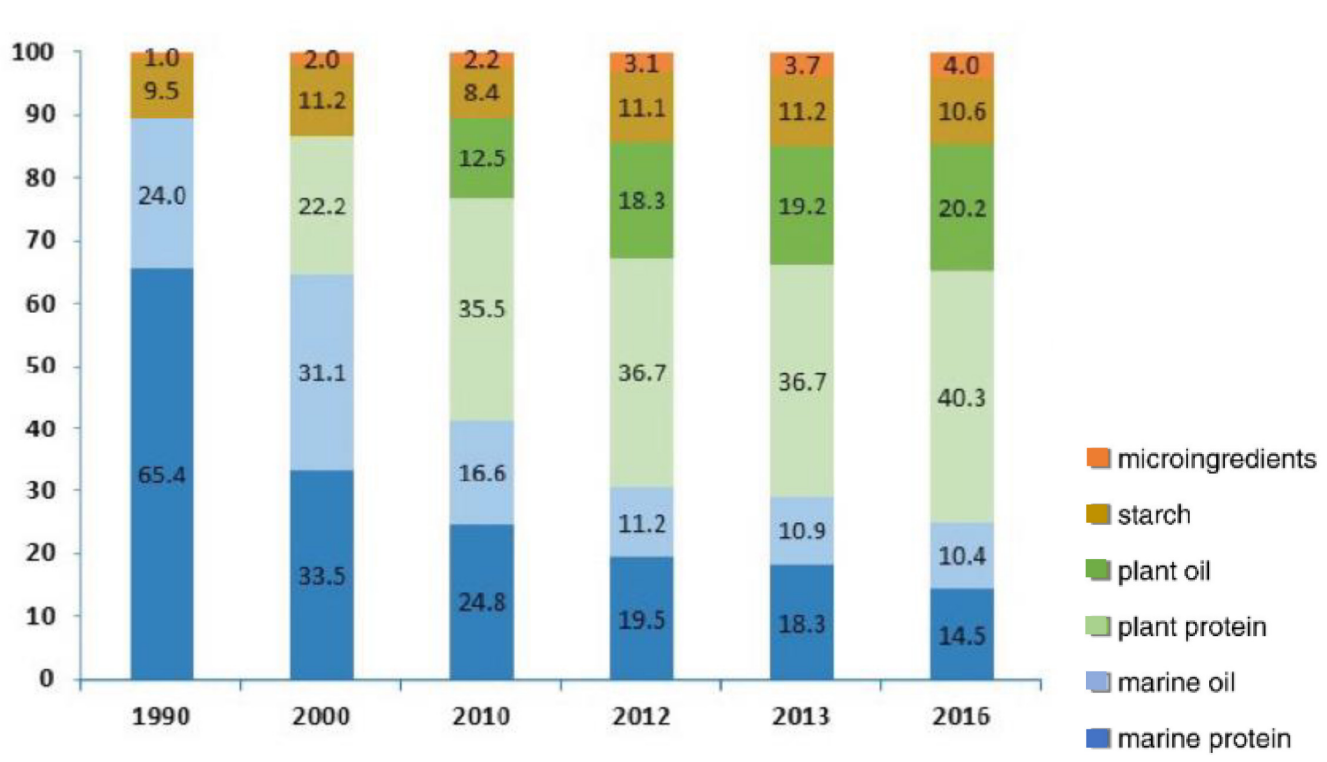

FIGURE 4 | Proportions of various ingredients in salmon feed in Norway, 1990-2016. Source: Aas et al. (2018, p. 41). 
salmon (Wwf.no, 2018), although ASC-certified salmon is still difficult to find in Norwegian stores (Røed, 2018).

\section{Actors and sustainability}

The focus on sustainability intensified during this period. This concern is evident in the farm-level standard and the principles on which it was based: "The principles serve as a platform to minimize or eliminate the social and environmental impacts of salmon aquaculture while permitting the salmon farming industry to remain economically viable" (ASC, 2017, p. 11). The SAD and the ASC certification system can be seen as an effort to join the three core issues of environmental, social, and economic sustainability more closely together. Two issues are of special interest: the use of wild fish and of soy in feed. A 2002 report from the environmental NGO Future in our hands (Framtiden i våre hender - FIVH) emphasized that most salmon feed came from valuable food fish (Strøm, 2002) and warned that the industry's continued growth would diminish those stocks. A newspaper article about this report (Ellingsen and Jakobsen, 2002) also referred to a 2000 report from the Chilean Ministry of Fisheries, which concluded that the production of fishmeal for aquaculture increased pressure on the already heavily exploited Chilean fish resources. Nonetheless, the Government of Norway sought to promote continued growth in the fish farming industry (White paper 36, 2001).

Later, the problems surrounding soy were accentuated. Several FIVH reports showed that since 2004 a rising proportion of the soy imported to Norway was used for fish farming; in 2013 it was 360,000 tons of 420000 total. As much as $80 \%$ of this comes from Brazil (Lindahl, 2014). Lindahl pointed out that the rainforest and other forest areas store enormous amounts of carbon, while soy plantations do not. Large-scale monocultures prevail at the expense of biodiversity, which is one of the reasons why so many species are threatened by extinction in areas dominated by agribusiness. Dasgupta et al. (2001) find how the amount of pesticides used in Brazil keeps rising. They also show that pesticides have been used to a greater extent on export crops than on non-export crops, where soybeans used more in total than any other crop. A more recent report by FIVH finds that soy producers are responsible for $52 \%$ of Brazil's total pesticide usage (Lundeberg and Grønlund, 2017). The range of pesticides allowed in Brazil is much greater than in Norway, where many types of pesticides are prohibited because of their harmful effects on human health and their disruption of whole ecosystems. In addition, agricultural production in some parts of the tropics (including Brazil) requires higher phosphorus application due to the phosphorus fixing characteristics of the soil (Roy et al., 2016). According to other reports, increasing pressure on natural resources leads to threats, violence, and even the murder of indigenous leaders and others who advocate for environmental conservation. Many conflicts are caused by agribusiness expansion on lands that indigenous communities occupy or claim as part of their traditional territory (FIVH and Rainforest Foundation Norway, 2018).

Regarding insects, in 2016 the EU Commission suggested approving processed protein from six different insect species as a feed source. This decision was influenced by the work of the
International Platform of Insects for Food and Feed (Petersen, 2016a), which promotes insects for human consumption and feed (Ipiff.org, 2017). In 2017, the EU regulation on insects for feed was adopted in Norwegian legislation (Mattilsynet, 2017). Erlend Sødal, CEO of Skretting, believes that using insect protein can help the company reach its sustainability goals (Petersen, 2016b). Another feed company, Cargill, is participating in a research project on insects funded by the Norwegian Research Council and coordinated by the National Institute of Nutrition and Seafood Research. Moreover, in 2018, the EU updated its food regulation to include insects (EC, 2018; EU, 2018), making it easier to produce and market insects for direct human consumption.

\section{DISCUSSION}

What does this story of transitions in salmon feed tell us about the sustainability of the bioeconomy? Have these transitions been sustainable, and what were their societal, economic, and environmental outcomes? Through discerning actors' interaction with technologies, institutions and sustainability framings, transition pathways can be traced to help us answer these questions.

\section{Transition Pathways}

In its first two or three decades, the development of dry feed was motivated more by seeking opportunity than by responding to challenges. Thus, the first part of the story is mainly an example of a type 1 transition, a transformation pathway. Many of the change agents were part of an existing sociotechnical regime, fisheries (Berge, 2001) and the agro-industrial complex, interacting with some outside innovative niches (e.g., feed producers). In the 1960s, these actors began to experiment with aquaculture. They had a variety of motives. Some scientists used fish to increase the efficiency of research in animal genetics; other actors, especially the Government of Norway, saw aquaculture as a way of gaining additional income from agriculture and in coastal districts (Jakobsen et al., 2003, p. 16). Other groups expressed concern about the harmful environmental effects of using wet feed. The development of dry fish feed is a good example of the gradual transfer and adaptation of a basic technology from a form used in animal raising to a new sector, fish farming. In the 1970s and 1980s, technologies originating from outside the agri-industrial regime-extrusion and vacuum coating-were adopted, making it possible to fine-tune the feed so it retained all the healthy fats.

There were only minor changes in institutions until the late 1980s and early 1990s. When the law on fish farming allowed the almost unlimited expansion of farms, aquaculture producers experienced increasing overproduction and faced a severe financial crisis. Then, through the engagement of actors outside the prevailing sociotechnical regime in the agricultural sector, especially key politicians, authorities, and banks, fish farming was "saved" by being radically transformed (see, e.g., Frisvoll, 2003; Fiskeri- og havbruksnæringens landsforening og Eksportutvalget for fisk, 2011). The main shifts were in actors and institutions, rather than technology. Large, centralized companies replaced 
small, family based local firms and were supported by a new set of institutional regulations. The introduction of feed quotas gave producers a strong incentive to make more efficient feed. The crisis around 1990 can be seen as a type of shock that rapidly created major tensions in the established aquaculture regime, and new solutions arose because of competition between old and new firms, especially concerning organization and regulation. The period from 1990 to 1996 can thus be termed a type 3 transition, $a$ substitution pathway. In this process, an active national policy and institutional regulation were important to support fish farming. The goal turned from ensuring livelihoods in rural areas to sustaining a national economic project.

After around 1996, landscape pressure eased somewhat. In contrast to the situation in the 1950s and 1960s, however, the basic technology for feeding fish was now sufficiently developed so that the regime underwent a type 2 transition, a reconfiguration pathway. Since then, sociotechnical development has concentrated on addressing various unintended consequences, such as unsustainable sources of feed, fish escapes, and fish diseases. These efforts have triggered further stepwise technological innovations within this regime. One of the major issues is the sustainable supply of soy, since increased production via monoculture has put pressure on rainforests and created social and environmental problems in the country of origin. This problem has triggered further innovations, such as research and experimentation on the use of insects and wood-fed microalgae as a source of feed. One can clearly see the "adoption of niche innovations to solve local problems" (Geels and Schot, 2007). The introduction of ASC certification demonstrates the formation of alliances between regime actors and environmental NGOs to create institutions that stimulate more sustainable practices in salmon farming, through measures that include regulating the sources of feed.

\section{A Sustainable Transition?}

The weight of landscape pressure and the availability of mature innovations play vital parts in shaping transition pathways. These factors, in turn, depend on the actions and interactions of individual and corporate actors and social groups, rules and institutions, and technologies in the wider sociotechnical system. Actors, technologies, and institutions are intertwined, rather than operating on their own. The innovations regarding feed, such as improvements in nutrition and the shift to more vegetablebased sources, did not happen in isolation. Nor can they be considered sustainable in and by themselves. It is the interaction among technology, actors, institutions, and understandings of sustainability that shapes the transition pathways of a given system. Actors play an especially important role as utilizers and interpreters of dynamics in sociotechnical systems, particularly as translators of sustainability concerns into policies and practices. In the initial period of fish feed development, they utilized existing technologies and resources and appealed to the concept of sustainability in order to produce more efficient feed and thus eventually strengthen the economic and social sustainability of the new sociotechnical system of salmon farming. In period two, institutions like the feed quota enabled actors to make feed that was even more efficient and provided them with real incentives for doing so, strengthening the industry's economic sustainability. The third period was marked not only by continued and more sustainable innovation in feed, but also by the formation of an alliance between regime actors, including salmon farm companies and environmental NGOs, to create a new institution, the ASC standard, that strengthened the industry's environmental sustainability.

How effectively did these shifts enable the fish farming and feed industry to meet the economic, environmental, and societal sustainability challenges it encountered over time? The findings indicate that not all the sustainability goals were equally important at all times. Sustainability issues were first related to pollution from the feed, then overfishing to make the feed, and most recently pressure on terrestrial areas for feed production, especially soy. In the first period, these concerns focused on employment and the sustenance of coastal communities: One of the reasons for the breakthrough of salmon farming was that it responded to the decline of fisheries after overfishing of wild fish (Strøm, 2002). Developing fish farming in areas that lacked other industries to compensate for the loss of traditional fisheries (Jakobsen et al., 2003, p. 16) was a way to secure the coastal districts of Norway (Frisvoll, 2003). Reducing the harmful environmental effects of wet feed was a supporting argument for the use of dry feed, which led to rapidly growth in the industry. After the economic crisis, when ownership of fish farms shifted from small, local firms to large corporations, national economic incentives for the industry were primary, and social sustainability was not treated as a high priority. As Frisvoll writes: "Factors from different areas have led to the government changing its goals with sea farming, from rural-political considerations to making it into a national growth industry" (Frisvoll, 2003, p. 1). At the same time, the Government of Norway used environmental arguments for why it introduced feed quotas, rather than emphasizing economic arguments. As Berge (2001) pointed out, one can speculate that it was an effort to gain legitimacy by demonstrating control over the industry and ameliorating pollution.

Although environmental sustainability could be argued to be only a supporting argument in the first periods, it gained much greater emphasis in the third, most recent period. The shift away from wild stock to more plant-based feed has had positive consequences for securing marine resources. However, the utilization of soy has exerted great pressure on terrestrial resources, a finding also in line with a recent study on shrimp feed. Malcorps et al. (2019) found that complete substitution of 20-30\% fishmeal, could lead to increasing demand for freshwater (up to $63 \%$ ), land (up to $81 \%$ ), and phosphorus (up to $83 \%$ ). The organization FIVH has even criticized the use of certified soy, as these certification schemes usually do not measure sustainability along the whole value chain (Lundeberg and Grønlund, 2017). In addition, the ASC standard has been criticized for not being strict enough: it allows the escape of up to 300 salmon per production cycle and the unlimited use of hydrogen peroxide (Berge, 2016). The literature also questions how much of an impact certification and standardization can have, since they have been created by private actors such as industrial corporations and NGOs and thus shift the power from public to private governance (see, e.g., Giovannucci and Ponte, 2005; Hatanaka et al., 2005). While 
some argue that social movements might help to ensure that retailers not only maximize their economic performance, but also the industry's social and environmental performance (Hatanaka et al., 2005), others argue that this view of sustainability is a much too narrow take on sustainability (Bosma et al., 2011; Bush et al., 2013). These NGOs must bring substantially more pressure for certification systems to adopt and enforce stricter criteria. That could increase the legitimacy, not only of certification systems themselves, but also of NGOs.

\section{A Reconfiguration Pathway Equals Weak Sustainability}

What, then, has actually been achieved through the reconfiguration pathway of salmon feed regarding sustainability? So far, it has only led to further unintended problems. One can argue that this outcome represents a form of weak sustainability, as the economic pillar in practice receives more emphasis than the social and environmental pillars. As Dedeurwaerdere (2014) explains, weak sustainability is based on the assumption that economic growth can be decoupled from material throughput through decrease of natural resource use in production systems, particularly by means of technological innovation. The figure published in Aas et al. (2018) shows that the proportion of animal ingredients in feed fell over a 20 -year period from around 90 percent to around 30 percent, and that the introduction of more plant ingredients was the main cause. This shift shows a relative decoupling, but does not necessarily make feed production more sustainable in absolute terms. The problems were simply shifted from the overexploitation and diminution of marine resources to the deleterious environmental and social consequences of soy monoculture. An unsustainable form of substitution is prevalent here: substituting natural capital instead of curbing certain resource-consuming activities, which may be unsupportable in the long term (Rideout, 2016). Moreover, this shift has merely transferred the problem from the marine environment closest to Norway to the global South. While the social consequences may be confined to Brazil, the loss of rainforest affects the global climate and has environmental consequences for Norway (and other countries).

The Government of Norway has announced its desire to increase the production of salmon in a predictable and environmentally sustainable way (White paper 16, 2015). "Growth [in salmon farming] contributes to increased value creation, increased employment, and increased prosperity for society." However, this stance presupposes a strong "environmental base" (p. 40) and assumes that rapid growth does not create serious problems that have no immediately available solutions. Salmon farming and feed development seems to be characterized by seeking to improve the environmental efficiency of our current economic systems, rather than challenging the underlying logics, goals and structures associated with those systems (see, e.g., Bina, 2013; Luederitz et al., 2017).

\section{Future Developments}

By applying the theoretical framework of the transition pathways outlined in Geels et al. (2016), it is possible to project potential pathways for the future development of the salmon and feed industry, and consider how actors, technologies, institutions, and sustainability framings interact and contribute to each pathway.

One possible pathway is an adjustment dominated reconfiguration, which is a continuation of the current reconfiguration pathway. If insects or microalgae grown on wood are used as new feed resources (see, e.g., Edebo, 2009; Lennartsson et al., 2011; Øverland and Skrede, 2017), this shift could lead to major reconfigurations and regime changes. As long as insects are fed on waste food rather than soy (Halloran et al., 2017), they could be a more sustainable source of proteins for fish feed. Farming insects that are quick and easy to produce in large quantities could facilitate continued growth in the industry, offering shorter supply chains and new employment possibilities without placing more pressure on terrestrial resources, therefore achieving more economic, environmental, and social sustainability. On the other hand, the propagation of insects for fish feed could have unintended consequences for neighboring systems. Potential pitfalls include a scenario where a significant number of these bugs escape, posing risks that cannot be ascertained. In addition, as some types of insects are already allowed as novel direct-consumption food, there is a real potential for a food vs. feed conflict to emerge. A feed versus food conflict would parallel the food versus fuel debate that arose in Norway regarding the best way to use resources sustainably. Another, more sobering option, is for the industry to be more strategic in its utilization of by-products. While this is already being done to some extent (FishFarmingExpert, 2019), a recent article accentuates that there is considerable potential to increase the sustainability of the industry through maximizing human edible yield by strategically managing by-products of salmon itself (Stevens et al., 2018). However, as with all use of by-products, it would require a constant production of these by-products, which does not necessarily contribute to reduction in resource use.

Another possible future substitution pathway would involve the more widespread acceptance of GMOs for feed and food. This could be the path if a heavy landscape pressure, for example unavailability of resources occurs. Even though certain GMOs was allowed for use in fish feed in Norway for quite some time, as long as the products were marked (Laksefakta.no, 2017b), the industry has stayed away from GMO feeds. As the Cargill representative, Einar Wathne, stated in the interview: "The customers and the salmon farmers don't want" GMO branding "on the salmon when they try to sell it." Yet he believes that this hostile attitude to GMO products will change when more information on their safety is available.

These two future pathways bear some similarities to the recent work of Vivien et al. (2019), which illustrates three competing narratives of what the bioeconomy entails. They outline three main narratives: the original sustainability-oriented narrative, as defined by N. Georgescu-Roegen in the 1970s and 1980s; a more science-oriented narrative; and a biomass-oriented narrative. They find that the last two are dominant. The science-oriented bioeconomy exhibits similarities to the substitution pathway, and the biomass-oriented bioeconomy resembles the continued reconfiguration pathway. According to Vivien et al., both entail 
a weak sustainability. For example, the science-oriented version could cause biosecurity risks and a loss of natural habitat through e.g., GMO, while the biomass-oriented version raises issues of land use, deforestation, the intensification of pollution from agro-industries, and risks for other ecosystems.

So what room is there for a more sustainable pathway? A third option, which is in line with the original sustainability narrative of the bioeconomy, depends on consumers changing their behavior more or less drastically to eat less salmon or eat insects directly, which both would not require the continued expansion of the salmon industry. This pathway would resemble a dealignment/realignment transition, which in this case could entail "strong" sustainability. The use of insects for feed could slowly change people's attitudes toward consuming insects directly, or a sudden increase in landscape pressure, for example a continued media and NGO advocacy of greater environmental sustainability, could diminish the legitimacy that the salmon industry now enjoys. Governmental recommendations for food consumption regarding health and climate issues could also increase landscape pressure. Since certain types of insects are already available for direct food consumption in the form of flour, such novel solutions might trigger niches to scale up on their own, enabling them to compete with the salmon industry. Species of fish lower down in the food chain, as well as algae, are other candidates for meeting humans' nutritional needs. A growing focus on vegetarian diets or alternatives to meat and poultry might help such industries thrive.

\section{CONCLUSION}

This case study exemplifies the processes through which a new "bioeconomic" food system develops at the intersection of existing sectors with the emergence and diffusion of innovations. The sociotechnical regimes of agriculture and fisheries converged in the creation of salmon farming, the transformation pathway. As the industry grew, it underwent a transition, shifting to an institutional substitution and then to a reconfiguration. This development was made possible not only through the interaction among actors, technologies, and institutions, but also through the utilization of different understandings of sustainability both by regime actors and by outside challengers who put pressure on the regime to change.

The salmon farming industry has presumably become more sustainable with innovations in feed. Efficient dry feed diminished pollution and facilitated its growth, ensuring the social sustainability of coastal communities. As feed quotas stimulated the production of even more efficient feeds, economic sustainability was given the highest priority. More recently, environmental sustainability has been given a greater focus. Nevertheless, economic sustainability continues to play the leading role. In the reconfiguration pathway the industry is currently in, new solutions and innovation in feed have only lead to new challenges. This outcome is especially clear with the cross-system effects and repercussions of increasing soy production in another ecosystem, which is currently prompting the industry to look elsewhere for feed. The continued search for new ingredients might lead to new environmental, animal welfare, or societal issues in salmon farming, at least if the salmon feed industry follows a reconfiguration pathway and keeps growing. Although feed might become even more efficient, creating a relative decoupling, the industry's continued expansion may prevent it from achieving an absolute decoupling. Moreover, setting aside all the other sustainability issues that might arise if salmon farming does not change, there is a real potential for a conflict between using natural resources to produce food and using them to produce feed.

At present, this bioeconomic industry suffers from the problems that figure largely in the critique of the bioeconomy agenda: its inability to take environmental concerns more seriously, substituting the feed input and moving the problems elsewhere, thereby ensuring only a weak sustainability. Before moving toward full-scale alternatives to soy, such as insect and microalgae farming, environmental impact assessments should be made regarding the potential conflicts and problems the use and production of these resources might lead to, especially the cross-system effects on neighboring eco-systems. In the eagerness to adopt bioeconomy strategies and live up to UN sustainability goals, caution must be exercised regarding the negative externalities that exploitation of fresh, non-waste biomass resources could have, especially if extracted from other ecosystems and in other countries.

\section{DATA AVAILABILITY STATEMENT}

The datasets generated for this study are not publicly available. The research project which this study is funded from, did not issue a statement that data generated must be published publicly. This study therefore adheres to this, especially regarding the interview transcripts. The informants were not asked if we could make the transcripts public either. However, the data material used for the media search is publicly available at https://www. retriever.no/. I refer to this site also in the "Materials and Methods" section.

\section{ETHICS STATEMENT}

Written informed consent was obtained from the individual(s) for the publication of any potentially identifiable images or data included in this article.

\section{AUTHOR CONTRIBUTIONS}

LH conceived and designed the research, undertook the primary research and analysis of the data collected.

\section{FUNDING}

The Research Council of Norway (Biosmart project no. 244608) provided funding that enabled me to undertake this study. 


\section{ACKNOWLEDGMENTS}

I would like to thank the informants for their valuable contributions and in particular Magnar Forbord and Per Olav

\section{REFERENCES}

Aarset, B., Jakobsen, S.-E., Iversen, A., and Ottesen, G. G. (2005). Lovverk, Teknologi og Etableringsbetingelser i Norsk Havbruk: Fase II. Bergen: Samfunnsog naeringslivsforskning AS.

Aas, T. S., Åsgård, T., and Ytrestøyl, T. (2018). Fôrressurser og deres utnyttelse i norsk lakseoppdrett. Nfexpert Nofima 2, 40-41.

Akvakulturloven (2005). Lov om Akvakultur (akvakulturloven). Oslo: Fiskeridepartementet.

ASC (2017). ASC Salmon Standard. Utrecht: Aquaculture Stewardship Council.

Asc-Aqua.org (2017). About Us. Available at: https://www.asc-aqua.org/about-us/ history/ (accessed May 23, 2017).

Asche, F. (2008). Farming the sea. Mar. Resour. Econ. 23, 527-547.

Asche, F., Roheim, C. A., and Smith, M. D. (2016). Trade intervention: not a silver bullet to address environmental externalities in global aquaculture. Mar. Policy 69, 194-201. doi: 10.1016/j.marpol.2015.06.021

Bailey, J. (2014). Looking for sustainable solutions in salmon aquaculture. Nordic J. Appl. Ethics 8, 22-40.

Bankefors, J., Kaszowska, M., Schlechtriem, C., Pickova, J., Brännäs, E., Edebo, L., et al. (2011). A comparison of the metabolic profile on intact tissue and extracts of muscle and liver of juvenile Atlantic salmon (Salmo salar L.)-Application to a short feeding study. Food Chem. 129, 1397-1405. doi: 10.1016/j.foodchem. 2011.05.081

Barbier, E. (1987). The concept of sustainable economic development. Environ. Conserv. 14, 101-110.

Berge, A. (2016). ASC-Sertifisering Får Kritikk. Bergen: ilaks.no.

Berge, D. M. (2001). Dansen Rundt Gullfisken: Naeringspolitikk og Statlig Regulering i Norsk Fiskeoppdrett 1970-1997. Bergen: Universitet i Bergen.

Bina, O. (2013). The green economy and sustainable development: an uneasy balance? Environ. Plann. C 31, 1023-1047. doi: 10.1068/c1310j

Bosma, R., Ahn, P. T., and Potting, J. (2011). Life cycle assessment of intensive striped catfish farming in the Mekong Delta for screening hotspots as input to environmental policy and research agenda. Int. J. Life Cycle Assess. 16, 903-915.

Bou, M., Berge, G. M., Baerverfjord, G., Sigholt, T., Østbye, T.-K., Romarheim, O. H., et al. (2017a). Requirements of n-3 very long-chain PUFA in Atlantic salmon (Salmo salar L): effects of different dietary levels of EPA and DHA on fish performance and tissue composition and integrity. Br. J. Nutr. 117, 30-47. doi: 10.1017/S0007114516004396

Bou, M., Berge, G. M., Baerverfjord, G., Sigholt, T., Østbye, T.-K., and Ruyter, B. (2017b). Low levels of very-long-chain n-3 PUFA in Atlantic salmon (Salmo salar) diet reduce fish robustness under challenging conditions in sea cages. J. Nutr. Sci. 6, 1-14. doi: 10.1017/jns.2017.28

Brundtland, G. H. (1987). Our Common Future. New York, NY: United Nations.

Brundtland, H. (2015). Knowledge Makes the Difference. Bergen: EWOS Forum, 2.

Bugge, M. M., Hansen, T., and Klitkou, A. (2016). What is the bioeconomy? A review of the literature. Sustainability 8:691. doi: 10.3390/su8070691

Bush, S. R., Belton, B., Hall, D., Vandergeest, P., Murray, F. J., Ponte, S., et al. (2013). Certify sustainable aquaculture? Science 341, 1067-1068.

Carter, C., and Hauler, R. (2000). Fish meal replacement by plant meals in extruded feeds for Atlantic salmon, Salmo salar L. Aquaculture 185, 299-311. doi: 10. 1016/s0044-8486(99)00353-1

Crampton, V. O., Nanton, D. A., Ruohonen, K., Skjervold, P. O., and El-Mowafi, A. (2010). Demonstration of salmon farming as a net producer of fish protein and oil. Aquacult. Nutr. 16, 437-446. doi: 10.1111/j.1365-2095.2010.00780.x

Czarniawska, B. (2004). Narratives in Social Science Research. London: Sage.

Dasgupta, P., and Heal, G. (1974). The optimal depletion of exhaustible resources. Rev. Econ. Stud. 41, 3-28. doi: 10.4324/9781315240084-1

Dasgupta, S., Mamingi, N., and Meisner, C. (2001). Pesticide use in Brazil in the era of agroindustrialization and globalization. Environ. Dev. Econ. 6, 459-482. doi: 10.1017/S1355770X01000262
Skjervold for their helpful advice and suggestions. A special thanks to Grey Osterud for her diligent proofreading. I am also grateful to Espen Moe and Rob Burton for their comments and suggestions.

Dedeurwaerdere, T. (2014). Sustainability Science for Strong Sustainability. Cheltenhamn: Edward Elgar Publishing.

Deutsch, L., Gräslund, S., Folke, C., Troell, M., Huitric, M., Kautsky, N., et al. (2007). Feeding aquaculture growth through globalization: exploitation of marine ecosystems for fishmeal. Glob. Environ. Change 17, 238-249. doi: 10. 1016/j.gloenvcha.2006.08.004

Dittrich, M., Giljum, S., Lutter, S., and Polzin, C. (2012). Green Economies Around the World. Implications of Resource Use for Development and the Environment. Vienna: SERI.

Dryzek, J. S. (2013). The Politics of the Earth: Environmental Discourses. Oxford: Oxford University Press.

Duchesne, L. C., and Wetzel, S. (2003). The bioeconomy and the forestry sector: changing markets and new opportunities. For. Chron. 79, 860-864. doi: 10. 5558/tfc79860-5

EC (2012). Innovating for Sustainable Growth: A/bioeconomy for Europe. Brussels: European Commision.

EC (2018). What is the Current Novel Food Legislation?. Brussels: European Commission.

Edebo, L. B. (2009). Zygomycetes for Fish Feed. Patent no: US20090136617A1.

Ekins, P., Simon, S., Deutsch, L., Folke, C., and De Groot, R. (2003). A framework for the practical application of the concepts of critical natural capital and strong sustainability. Ecol. Econ. 44, 165-185. doi: 10.1016/s0921-8009(02) 00272-0

Elkington, J. (1998). Cannibals with Forks: The Triple Bottom Line of Sustainability. Gabriola Island, BC: New Society Publishers.

Ellingsen, P., and Jakobsen, O. (2002). Lakseoppdrett er Matsløseri. Dagbladet. Oslo: Retriever Norge.

EU (2018). Regulation (EU) 2015/2283 of the European Parliament and of the Council on Novel Foods, Amending Regulation (EU) No 1169/2011 of the European Parliament and of the Council and Repealing Regulation (EC) No 258/97 of the European Parliament and of the Council and Commission Regulation (EC). No 1852/2001 The European Parliament And The Council Of The European Union. Brussels: European Union.

EuropaBio (2011). Building a Bio-Based Economy for Europe in 2020. Brussels: European Association for Bioindustries.

European Technology Platforms (2017). The European Bioeconomy in 2030. Delivering Sustainable Growth by Addressing the Grand Societal Challenges. Wallonia: European Technology Platforms.

Evers, A., and Laville, J.-L. (2004). "Defining the third sector in Europe," in The Third Sector in Europe, eds A. Evers, and J.-L. Laville, (Cheltenham: Edward Elgar), 11-42.

Falk-Andersson, J., Forbord, M., and Vennesland, B. (2016). Mapping the Bioeconomy: Biological Resources and Production in Forestry, Agriculture, Fisheries and Aquaculture Across Norway, Norut Report 16/2016. Tromsø: Norut.

FAO (2016). The State of World Fisheries and Aquaculture. Rome: Food and Agriculture Organization of the United Nations.

FishFarmingExpert (2019). Cargill Marine Content of Feed Reduced in 2018. Available at: https://www.fishfarmingexpert.com/article/cargill-marinecontent-of-feed-reduced-in-2018/ (accessed June 11, 2019).

Fiskeri- og havbruksnæringens landsforening og Eksportutvalget for fisk (2011). Norsk Havbruk. Available at: https://sjomatnorge.no/wp-content/uploads/ 2014/04/eff_fhl_komplett_lowres.pdf

FIVH and Rainforest Foundation Norway (2018). Salmon on Soy Beans Deforestation and Land Conflict in Brazil. Oslo: Framtiden i våre hender and Rainforest Foundation Norway.

Floros, J. D., Newsome, R., Fisher, W., Barbosa-Cánovas, G. V., Chen, H., Dunne, C. P., et al. (2010). Feeding the world today and tomorrow: the importance of food science and technology: an IFT scientific review. Compr. Rev. Food Sci. Food Saf. 9, 572-599. doi: 10.1111/j.1541-4337.2010.00127.x 
Forbord, M., Falk-Andersson, J., Riseth, J. Å, and Vennesland, B. (2017). Current Industrial Uses of Biological Resources and Products in Norway. A Cross-Sectoral View on the Bioeconomy. Tromsø: NORUT Northern Research Institute.

Frisvoll, S. (2003). Beslutningsprosesser i Havbruket-Lokale Eieres Valg i Møte med Globale og Lokale Forhold. Trondheim: Norsk senter for bygdeforskning, 7.

Geels, F. W. (2002). Technological transitions as evolutionary reconfiguration processes: a multi-level perspective and a case-study. Res. Policy 31, 1257-1274. doi: 10.1016/s0048-7333(02)00062-8

Geels, F. W. (2004). From sectoral systems of innovation to socio-technical systems. Res. Policy 33, 897-920. doi: 10.1073/pnas.1525004113

Geels, F. W. (2005). The dynamics of transitions in socio-technical systems: a multi-level analysis of the transition pathway from horse-drawn carriages to automobiles (1860-1930). Technol. Anal. Strat. Manag. 17, 445-476. doi: 10. $1080 / 09537320500357319$

Geels, F. W. (2010). Ontologies, socio-technical transitions (to sustainability), and the multi-level perspective. Res. Policy 39, 495-510. doi: 10.1016/j.respol.2010. 01.022

Geels, F. W., Kern, F., Fuchs, G., Hinderer, N., Kungl, G., Mylan, J., et al. (2016). The enactment of socio-technical transition pathways: a reformulated typology and a comparative multi-level analysis of the German and UK low-carbon electricity transitions (1990-2014). Res. Policy 45, 896-913. doi: 10.1016/j. respol.2016.01.015

Geels, F. W., and Schot, J. (2007). Typology of sociotechnical transition pathways. Res. Policy 36, 399-417. doi: 10.1016/j.respol.2007.01.003

Giddings, B., Hopwood, B., and O’Brien, G. (2002). Environment, economy and society: fitting them together into sustainable development. Sustain. Dev. 10, 187-196. doi: 10.1002/sd.199

Giovannucci, D., and Ponte, S. (2005). Standards as a new form of social contract? Sustainability initiatives in the coffee industry. Food Policy 30, 284-301. doi: 10.1016/j.foodpol.2005.05.007

Government of Norway (2016). Kjente Ressurser - Uante Muligheter. Regjeringens Bioøkonomistrategi. Oslo: Government of Norway.

Halloran, A., Hanboonsong, Y., Roos, N., and Bruun, S. (2017). Life cycle assessment of cricket farming in north-eastern Thailand. J. Clean. Product. 156, 83-94. doi: 10.1016/j.jclepro.2017.04.017

Hanssen, T. M., and Lie, E. (2012). Fish Feed for Sustainable Aquaculture. Tromsø: Aquaculture Protein Centre (APC).

Hatanaka, M., Bain, C., and Busch, L. (2005). Third-party certification in the global agrifood system. Food Policy 30, 354-369. doi: 10.1016/j.foodpol.2005.05.006

Havforskningsinstituttet (2015). Insekter Som Sterolkilde for Atlanterhavslaks. Bergen: Havforskningsinstituttet.

Hilborn, R. (2013). Environmental cost of conservation victories. Proc. Natl. Acad. Sci. U.S.A. 110, 9187-9187. doi: 10.1073/pnas.1308962110

Ipiff.org (2017). International Platform of Insects for Food and Feed. Available at: http://ipiff.org/ (accessed February 27, 2017).

Jackson, T. (2009). Prosperity Without Growth: Economics for a Finite Planet. Abingdon: Routledge.

Jakobsen, S.-E., Berge, D. M., and Aarset, B. (2003). Regionale og Distriktspolitiske Effekter av Statlig Havbrukspolitikk. Bergen: Samfunnsog naeringslivsforskning AS.

Kemp, R. P. M., Rip, A., and Schot, J. (2001). "Constructing transition paths through the management of niches," in Path Dependence and Creation eds R. G. Kemp, and P. Karnoe, (London: Lawrence Erlbaum), 269-299.

Kleivdal, H., Chauton, M. S., and Reitan, K. I. (2013). ProAlgae. Industrial Production of Marine Microalgae as a Source of EPA and DHA Rich Raw Material in Fish Feed - Basis, Knowledge Status and Possibilities. Final report. Bergen: Uni Research/SINTEF.

Kyst.no (2017). Førti år Med Fiskefôr. Available at: https://www.kyst.no/article/ foerti-aar-med-fiskefor/ (accessed February 15, 2017)

Laksefakta (2017a). Er laksefôr baerekraftig? Available at: https://laksefakta.no/hvaspiser-laksen/er-lakseforet-barekraftig-er-det-villfisk-i-lakseforet/ (accessed February 15, 2017).

Laksefakta (2017b). Spiser Laksen Genmodifiserte Råvarer?. Available at: https://laksefakta.no/hva-spiser-laksen/spiser-laksen-genmodifiserte-ravarer/ (accessed February 15, 2017)

Lennartsson, P. R., Erlandsson, P., and Taherzadeh, M. (2014). Integration of the first and second generation bioethanol processes and the importance of by-products. Bioresour. Technol. 165, 3-8. doi: 10.1016/j.biortech.2014. 01.127

Lennartsson, P. R., Niklasson, C., and Taherzadeh, M. (2011). A pilot study on lignocelluloses to ethanol and fish feed using NMMO pretreatment and cultivation with zygomycetes in an air-lift reactor. Bioresour. Technol. 102, 4425-4432. doi: 10.1016/j.biortech.2010.12.089

Lindahl, H. (2014). Godt Brasiliansk. En Kartlegging av Soyaforbruket $i$ Norsk Landbruk og Oppdrettsnaering. Oslo: Framtiden i våre hender, 4.

Little, D. C., Young, J. A., Zhang, W., Newton, R. W., Al Mamun, A., and Murray, F. J. (2018). Sustainable intensification of aquaculture value chains between Asia and Europe: a framework for understanding impacts and challenges. Aquaculture 493, 338-354. doi: 10.1016/j.aquaculture.2017.12.033

Luederitz, C., Abson, D. J., Audet, R., and Lang, D. J. (2017). Many pathways toward sustainability: not conflict but co-learning between transition narratives. Sustain. Sci. 12, 393-407. doi: 10.1007/s11625-016-0414-0

Lund Declaration (2009). Europe Must Focus on the Grand Challenges of Our Time. Belgium: Swedish EU Presidency.

Lundeberg, H., and Grønlund, A. L. (2017). Fra Brasiliansk Jord til Norske Middagsbord. En Rapport om Soya i Norsk Laksefôr. Oslo: Regnskogfondet og Framtiden i våre hender.

Malcorps, W., Kok, B., van't Land, M., Fritz, M., van Doren, D., Servin, K., et al. (2019). The sustainability conundrum of fishmeal substitution by plant ingredients in shrimp feeds. Sustainability 11:1212. doi: 10.3390/su11041212

Mattilsynet (2017). Insekter til Bruk i fôr. Available at: https://www.mattilsynet. no/dyr_og_dyrehold/for/insekter_til_bruk_i_for.25298 (accessed February 27, 2017).

McCormick, K., and Kautto, N. (2013). The bioeconomy in Europe: an overview. Sustainability 5, 2589-2608. doi: 10.3390/su5062589

Moses, J., and Knutsen, T. (2012). Ways of Knowing: Competing Methodologies in Social and Political Research. New York, NY: Palgrave Macmillan.

Naylor, R. L., Goldburg, R. J., Primavera, J. H., Kautsky, N., Beveridge, M. C. M., Clay, J., et al. (2000). Effect of aquaculture on world fish supplies. Nature 405, 1017-1024.

Newton, R. W., and Little, D. C. (2018). Mapping the impacts of farmed Scottish salmon from a life cycle perspective. Int. J. Life Cycle Assess. 23, 1018-1029. doi: 10.1007/s11367-017-1386-8

Noël, J.-F., and O'Connor, M. (1998). “Strong sustainability and critical natural capital," in Valuation for Sustainable Development: Methods and Policy Indicators, ed. S. F. M. O'Connor, (Cheltenham: Edward Elgar), 75-97.

Nofima, (2014). Sunndalsøra Research Station. Tromsø: Nofima.

NOU (1977). Fiskeoppdrett: Utredning Fra et Utvalg Oppnevnt Ved Kongelig Resolusjon 25. Februar 1972; Utredningen Avgitt til Fiskeridepartementet Lysøutvalget. Oslo: Universitetsforlaget, 39.

OECD (2009). The Bioeconomy to 2030: Designing a Policy Agenda. Paris: OECD.

Ollikainen, M. (2014). Forestry in bioeconomy-smart green growth for humankind. Scand. J. For. Res. 29, 360-366. doi: 10.1080/02827581.2014. 926392

Øverland, M., and Skrede, A. (2017). Yeast derived from lignocellulosic biomass as a sustainable feed resource for use in aquaculture. J. Sci. Food Agric. 97, 733-742. doi: $10.1002 /$ jsfa. 8007

Pelenc, J., and Ballet, J. (2015). Strong sustainability, critical natural capital and the capability approach. Ecol. Econ. 112, 36-44. doi: 10.1016/j.ecolecon.2015.02. 006

Pestoff, V. A. (1992). Third sector and co-operative services - An alternative to privatization. J. Consum. Policy 15, 21-45. doi: 10.1007/BF01016352

Petersen, M. (2016a). Insekter Gir Muligheter. Available at: https: //www.kyst.no/article/insekter-gir-muligheter/ (accessed February 27, 2017).

Petersen, M. (2016b). Insekterfôr Godkjent for Bruk i EU. Available at: https: //www.kyst.no/article/insekterfor-godkjent-for-bruk-i-eu/ (accessed February 27, 2017).

Richardsen, R., Nystøyl, R., Strandheim, G., and Viken, A. (2015). Analyse Marint Restråstoff, 2014 Analyse av Tilgang og Anvendelse for Marint Restråstoff $i$ Norge. Trondheim: Sintef Fiskeri og havbruk.

Rideout, M. (2016). Smallholder New Entrants: Italy's Organic Sector and the Changing Face of Agriculture. Department of Earth Sciences. Uppsala: Uppsala University. 
Røed, H. (2018). Er Sertifisert Oppdrettslaks Godt Nok? Available at: https://www.aperitif.no/artikler/er-sertifisert-oppdrettslaks-godt-nok/432350 (accessed March 10, 2018).

Roy, E. D., Richards, P. D., Martinelli, L. A., Coletta, L. D., Lins, S. R. M., Vazquez, F. F., et al. (2016). The phosphorus cost of agricultural intensification in the tropics. Nat. Plants 2:16043. doi: 10.1038/nplants.2016.43

Sánchez-Muros, M.-J., Barroso, F. G., and Manzano-Agugliaro, F. (2014). Insect meal as renewable source of food for animal feeding: a review. J. Clean. Product. 65, 16-27. doi: 10.1016/j.jclepro.2013.11.068

Sans, P., and Combris, P. (2015). World meat consumption patterns: an overview of the last fifty years (1961-2011). Meat Sci. 109, 106-111. doi: 10.1016/j. meatsci.2015.05.012

Scarlat, N., Dallemand, J.-F., Monforti-Ferrario, F., and Nita, V. (2015). The role of biomass and bioenergy in a future bioeconomy: policies and facts. Environ. Dev. 15, 3-34. doi: 10.1016/j.envdev.2015.03.006

Skjervold, P. O. (2015). Akvakulturhistorien - Fortellingen om en Suksess. Tromsø: Vitenparken Campus Ås.

Skrede, A. (2015). Fôret til Laksen - fra Prøving og Feiling til Forskningsbasert Industriell Suksess. Akvakulturhistorien - Fortellingen om en Suksess. Tromsø: Vitenparken Campus Ås.

Solow, R. M. (1974). Intergenerational equity and exhaustible resources. Rev. Econ. Stud. 41, 29-45.

Soltveit, T. (2016). Hundre Anlegg Har Oppnådd ASC Sertifisering. Available at: https://www.kyst.no/article/hundre-anlegg-har-oppnaadd-asc-sertifisering/ (accessed May 23, 2017).

Staffas, L., Gustavsson, M., and McCormick, K. (2013). Strategies and policies for the bioeconomy and bio-based economy: an analysis of official national approaches. Sustainability 5, 2751-2769. doi: 10.3390/su5062751

Stevens, J. R., Newton, R. W., Tlusty, M., and Little, D. C. (2018). The rise of aquaculture by-products: increasing food production, value, and sustainability through strategic utilisation. Mar. Policy 90, 115-124. doi: 10.1016/j.marpol. 2017.12.027

Strøm, T. (2002). Matproduksjon Eller Matdestruksjon. Oslo: Framtiden i våre henders forskningsinstitutt, 2.

Swinnen, J., and Riera, O. (2013). The global bio-economy. Agric. Econ. 44, 1-5. doi: 10.1111 /agec. 12045

UNDP (2011). Sustainability and Equity: A Better Future for All. New York, NY: United Nations Development Programme (UNDP).
United Nations (2015). Transforming Our World: The 2030 Agenda for Sustainable Development. Resolution adopted by the General Assembly on 25 September 2015. New York, NY: United Nations.

Unruh, G. C. (2000). Understanding carbon lock-in. Energy Policy 28, 817-830. doi: $10.1039 / \mathrm{c} 3 \operatorname{cs} 35483 \mathrm{k}$

Vivien, F.-D., Nieddu, M., Befort, N., Debref, R., and Giampietro, M. (2019). The hijacking of the bioeconomy. Ecol. Econ. 159, 189-197. doi: 10.1016/j.ecolecon. 2019.01.027

White paper 16 (2015). Meld. St. 16 (2014-2015) Forutsigbar og Miljømessig Baerekraftig Vekst $i$ Norsk Lakse- og Ørretoppdrett. Oslo: Naerings- og fiskeridepartementet.

White paper 36 (2001). St.meld. nr. 36 (2000-2001) SND: Ny giv, ny Vekst, Nytt Naeringsliv. Oslo: Naerings- og handelsdepartementet.

White paper 71 (1980). St.meld. nr. 71 (1979-80) Om Offentlig Medvirkning Til Utvikling Til Fiskeoppdrettsnaeringen. Oslo: Fiskeridepartementet.

WorldWildfLife.org (2018). Creating Standards for Responsibly Farmed Salmon. Available at: https:/www.worldwildlife.org/pages/creating-standards-forresponsibly-farmed-salmon (accessed March 10, 2018).

Wwf.no, (2018). Miljøvennlig og Berekraftig Fiskeoppdrett. Available at: https://www.wwf.no/dyr-og-natur/hav-og-fiske/milj\%C3\%B8vennlig-b\% C3\%A6rekraftig-fiskeoppdrett (accessed March 10, 2018).

Yin, R. (2003). Case Study Research: Design and Methods. Thousand Oaks: Sage.

Ytrestøyl, T., Aas, T. S., and Åsgård, T. (2014). Resource Utilisation of Norwegian Salmon Farming in 2012. Tromsø: Nofima.

Ytrestøyl, T., Aas, T. S., and Åsgård, T. (2015). Utilisation of feed resources in production of Atlantic salmon (Salmo salar) in Norway. Aquaculture 448, 365-374. doi: 10.1016/j.aquaculture.2015.06.023

Conflict of Interest: The author declares that the research was conducted in the absence of any commercial or financial relationships that could be construed as a potential conflict of interest.

Copyright (c) 2019 Hansen. This is an open-access article distributed under the terms of the Creative Commons Attribution License (CC BY). The use, distribution or reproduction in other forums is permitted, provided the original author(s) and the copyright owner(s) are credited and that the original publication in this journal is cited, in accordance with accepted academic practice. No use, distribution or reproduction is permitted which does not comply with these terms. 